\title{
A Profile of Organic Food Consumers-Serbia Case-Study
}

\author{
Vuk Radojević, Mirela Tomaš Simin * (1), Danica Glavaš Trbić and Dragan Milić
}

Faculty of Agriculture, University of Novi Sad, TrgDositejaObradovića 8, 21000 Novi Sad, Serbia; rvuk@polj.uns.ac.rs (V.R.); danicagt@polj.uns.ac.rs (D.G.T.); dragan.milic@polj.edu.rs (D.M.)

* Correspondence: mirela.tomas@polj.edu.rs; Tel.: +381-62-240-123

check for

updates

Citation: Radojević, V.; Tomaš Simin, M.; Glavaš Trbić, D.; Milić, D. A Profile of Organic Food Consumers-Serbia Case-Study. Sustainability 2021, 13, 131. https://dx.doi.org/10.3390/su13010 131

\section{Received: 13 October 2020}

Accepted: 16 December 2020

Published: 25 December 2020

Publisher's Note: MDPI stays neutral with regard to jurisdictional claims in published maps and institutional affiliations.

Copyright: () 2020 by the authors. Licensee MDPI, Basel, Switzerland. This article is an open access article distributed under the terms and conditions of the Creative Commons Attribution (CC BY) license (https: / creativecommons.org/ licenses/by/4.0/).

\begin{abstract}
In this paper, the authors analyze products from the organic farming system from consumption and consumers. The research aimed to determine the characteristics of the Serbian organic market, discover attitudes, practices, and features of different organic food consumers and identify factors that influence organic products' purchase. This was done following the theoretical framework of green marketing, which refers to the holistic management process responsible for identifying, anticipating, and satisfying customers and society's needs for profitably and sustainability. The research for this study was conducted in Novi Sad and Belgrade in late 2015 and early 2016. The sample included 496 respondents over 18 years of age, varying levels of education, marital status, and other sociodemographic characteristics. The sample was divided into three internally homogeneous yet mutually heterogeneous clusters according to three criteria: factors that generally influence their food purchasing decisions, their opinions regarding characteristics of food products and their eating habits, and their sociodemographic characteristics. The analysis shows that organic consumers can be divided into three clusters with corresponding components related to aspects of products that are sold in the Serbian market. In Cluster 1, respondents who assign the least importance to whether they eat "healthy" products and to the number of calories in those products are presented. Cluster 2 respondents care most about what they consume, and in Cluster 3, respondents assign importance to eat "healthy" food. The findings of this study show that the decision whether to buy organic products or not is predominantly determined by the price and quality of products (which is also related to the socio-economic characteristics of consumers) so that eco-marketing should therefore be more directed towards those consumers who are already "more environmentally and health-conscious", because in this way, the desired results of improving the domestic market of organic products will be achieved.
\end{abstract}

Keywords: organic production; consumption; sustainability; green marketing; organic consumer

\section{Introduction}

Agriculture is considered the most significant strategic economic branch that aims to produce food that is of good quality and safe to consume. However, the question of how healthy and safe the produced food is for human consumption is not easy to answer. The growing needs of the population and rapid modernization of agriculture have transformed the ecosystem and its utilization in agricultural production, intensifying the exploitation of the soil, water, forests, and other natural resources. In turn, this has caused excessive use - frequently unchecked — of agrichemicals to protect plants and enhance their growth and fertility, thereby posing a threat to the production of safe and healthy food of high quality, human and animal health, and natural cycles critical for the survival of all life on Earth [1,2].

Organic agriculture has emerged as a response to a high degree of chemicalization in the primary agricultural production, a loss in biodiversity, and an increasing number of consumers who suffer adverse health effects, predominantly in highly industrialized countries [3]. As organic agriculture is gaining prominence, there is a need to compare organic and conventional farming methods to their impact on the environment [4,5]. Since organic 
farming aims at sustainability, it is considered less damaging for the environment than conventional farming, which relies more heavily on external inputs [6].

Unlike conventional agricultural production, organic food production is based on the biological balance of the soil-plant-animal-human system. As a sustainable agriculture system, organic food production observes ecological principles. It aims to produce food with high nutritional value, the development of sustainable agriculture coupled with ecosystem preservation and soil fertility improvement [7]. A system of organic production includes the uttermost application of renewable energy sources, safeguarding genetic diversity of the agroecosystem, conservation of the environment, and the reduction of all types of pollution caused by agricultural production to create conditions in which agricultural producers can satisfy their basic needs and make an adequate profit $[1,2]$. For all these reasons, the study of the organic food market is highly significant because of the great demand for these products, which correlates with consumers' increased awareness and their attentiveness to health and environmental concerns [8]. Furthermore, there are also differences in the purchasing power and lifestyle between groups of consumers who can and want to afford these products.

As general concern about the environment and sustainability has grown, so has the popularity of "green marketing". Sarkar [9] argues that sustainability is not merely "an internal reform movement" within companies. Still, it serves as a "bridge between business and green [10] ensuring a better quality of life for everyone, now and for generations to come." Green marketing has twin objectives of minimizing environmental harm while securing economic benefits. "Green marketing" is defined by Peattie [11] as "the holistic management process responsible for identifying, anticipating and satisfying the needs of customers and society, profitably and sustainably." Sarkar [9] suggests that the objective of green marketing is to educate and encourage people to "go green", leading them to change their lifestyle and behavior. In their analysis of the term "green", Simula and Lehtimäki [12] claim that it is widely used to describe new technologies and new products which incorporate the principle of sustainability and have a positive impact on the environment. "Green", "pro-environmental", "sustainability", "environmentally friendly", and "ecology" are commonly used to indicate that a company's products and production processes are energy-efficient, recycling-oriented, produce less waste and pollution, and conserve the environment.

The consumption of organic food products is predicated on public awareness about growing environmental problems. It is thought that this fact, coupled with the introduction into people's lifestyle of strategies to encourage them to purchase organic products, will contribute to increased profits of economic subjects. Eco-marketing does not have the same effect on all buyers. Therefore, it is necessary to target particular markets and direct promotional activities at specific groups of people who are "concerned" about their health and the environment. Green marketing offers a possibility for people to be active and promote "green" lifestyles. On the other hand, companies can explore innovative business solutions to secure both economic success and consumers' trust $[2,9]$.

For green marketing to achieve its above goals, it is necessary to research and define organic products' consumers. In their study, Feil et al. [13] state that the motives for consuming organic products are complex, especially concerning the sociodemographic characteristics of consumers. In their research, Falguera et al. [14] state that people with higher incomes (and married couples) show more positive attitudes and prefer to consume organic food. Similarly, in a study conducted in Switzerland [15], one of the starting assumptions was that increased daily consumption of organic products is influenced by sociodemographic variables such as higher incomes and higher education levels. Confirming these findings, Chekima et al. [16,17] draw attention to the fact that it is necessary to pay additional attention and investigate the difference or the so-called "gap" between the intention to buy organic products and the specific consumption of these products. Vehapi [18], in his research of organic consumers in Serbia, states that health is the most crucial motive for buying organic food. What still characterizes consumers in this market, according to him, 
is the insufficient presence of ethical and environmental reasons when purchasing organic food, which distinguishes them from consumers in developed countries. Consumers who do not buy organic food products or buy them very rarely and in limited quantities do so because of the higher price of these products compared to similar products from conventional production. Grubor and Djokić [19] conducted a conjoint and cluster analysis to data about Serbian consumers in the organic sector. The mentioned authors state that the market of organic products in Serbia is insufficiently researched and that it is generally characterized by scarce food consumer research.

In an attempt to address these shortcomings, this research was conducted to determine the characteristics of the Serbian organic market, discover attitudes, practices, and identify factors that influence the purchase of organic products, that is, to define the organic consumer profile in Serbia. The uniqueness and originality of this research stems from the fact (mentioned in the previous paragraph) that this type of research is covered relatively little in scientific research on the territory of the Republic of Serbia. This study is among few conducted on this territory, organized to analyze the consumer behavior towards organic products, contributing to enrich that part of the economic literature which states that consumers have a positive attitude towards organic products. Given the fact that the very concept of organic agriculture in Serbia has been current for some twenty years (since 1990, when the first organizations in this field appeared) [20], it is necessary to make additional efforts in researching the market and consumers of these products. Especially if one keeps in mind the fact that organic agriculture emphasizes the importance of the local market and local product purchases. Relying on both original and derived data, using the appropriate methods, relevant elements will be identified, which play a significant role in improving the consumption of organic products in the Republic of Serbia. The findings of this study could potentially apply to other countries with a similar socio-economic level of development.

The paper's structure is as follows: In the first part of the article (Introduction), the fundamental determinants (green marketing, organic agriculture) are presented together with the initial hypotheses. The literature review shortly presents past research related to the subject area. After that, the material and used methods and sources are presented. The results ofthe discussion present the obtained results with references from other research related to the same topic. The last part of the paper refers to the authors conclusions based on the presented results.

\section{Literature Review}

Early studies focused on ad hoc research into sustainable food production systems, eco-marketing, and factors influencing food purchasing decisions. Eco-marketing is a part of economic theory which is focused on researching the market itself and its components. For example, Shabbir et al. [21] define green or eco-marketing as marketing that encompasses all activities to promote any change to satisfy a human need or desire that has a minimal detrimental impact on the natural environment. This definition contains the traditional components of the definition of marketing (consumer satisfaction), but also contains environmental protection, in a way that minimizes the harmful impact on the environment (to be accurate, the eco-claim on the product should read "less harmful to the environment", not "environmentally friendly").

A certain part of previous research was related to determining the factors that influence consumer decisions when buying environmentally friendly products. One of the first studies that brought to the forefront the attitude of consumers towards the price of products from organic agriculture is a study conducted in Italy in 1992 [22]. The basic assumption that guided it is that information on the market is insufficient, and that when making a purchase decision, the currently valid (objective) price is not considered, but the consumer's choice to buy is based on the fact of what consumers believe that the price should be at that moment (subjective price). In addition, one of the earlier studies was conducted by Margetts et al. [23]. In their study, when asked to assess the choice of diet in the future, $32 \%$ of respondents put 
future efforts to use "healthy" food in the first place. The decision on the choice of food is most often made by women, and the price of food has proven to be a decisivefactor only for pensioners and the unemployed. Special emphasis during the research was given to examining the influence of the level of education of the respondents on the choice of "healthy" food, and the result indicates that this is the factor of the strongest influence. Torjusen et al. [24] explored the potential of organic agriculture, starting from the view that it is very important to know both consumers and producers thinking about food quality and systemic issues. Multivariate analysis has shown that traditional aspects of food quality, such as freshness and taste, are especially important for consumers. Additionally, those who bought organic food were more concerned about ethical, environmental, and health issues and consumer orientations in the food market were identified. Wier et al. [25] explored organic food markets in the UK and Denmark, identifying major differences and similarities in consumer perceptions and priorities, labelling schemes, and sales channels as a basis for assessing market stability and future growth prospects. The authors found that decisions to buy organic food were primarily motivated by "private" attributes such as freshness, taste, and health. Gracia and de Magistris [26] analyzed the demands of organic food consumers in southern Italy. The authors hypothesized that consumer behavior depends on the characteristics of the product instead of the product itself. In this way, consumers will choose a product (organic vs. conventional) that has a combination of attributes that increase utility. Garg et al. [27] state in research that consumers, regardless of their differences by segments, in all developed countries, are not satisfied with having enough food but they want to be able to choose foods that will maximally protect and improve their health. Nie and Zepeda [28] with the so-called food-related lifestyle model, widely used in European research, research the consumption of organic and local food. The authors also segmented consumers and compared segments with respect to organic and local food consumption variables. They correlated with environmental concerns, knowledge and practice, practices, and health concerns, as well as some demographic characteristics (race, gender, age, education), income, and variables that measured access to these foods. Van Huy et al. [29] applied the unique food-related lifestyles (FRL) approach to segment organic food consumers in Vietnam. Data were obtained from 203 organic food consumers, and a two-step cluster analysis established three identifiable market segments which we named "Conservatives", "Trendsetters", and "Unengaged". The Conservatives were interested in the health aspects of food and preferred natural products. The Trendsetters were interested in healthy food, liked to cook, and held a positive attitude toward organic food and local food products. The Unengaged consumers were not concerned about food-related issues, and they reported the least consumption of organic food. In their research, certain authors turn to the market of individual products determining what motivates consumers to buy specific products. In their research, Migliore et al. [30] tried to understand which wine quality characteristics, consumers' attitudes, and socio-demographic characteristics affect the consumers' willingness to pay (WTP) a premium price for a bottle of natural wine. The research results reveal that drink frequency and occasion, organic production method, the content of sulfites, income, and the attitudes towards healthy eating and the environment are positively associated with a higher WTP for natural wine. Likewise, Drugova et al. [31] examined determinants of consumer interest in organic versions of wheat products by analyzing differences in selected factors among groups of consumers, distinguished by their likelihood of purchasing organic wheat products. They conclude that consumer preferences and willingness to pay (WTP) for organic foods depend on product type. Additionally, significant differences are found across consumer groups-regardless of product type-in the importance they place on labels and product characteristics, WTP, reasons for (not) purchasing organic products, and consumption limitations.

Novel studies are also focused on consumer's behavior in the organic market, as well as their intentions and decision-making factors. Unlike previous studies, some modern research focuses on developing countries and the market for organic products. Pacho [32] empirically examined the impact of attitude, subjective norms, and perceived behavior control on the consumer intention to buy organic food. The author stated that the behavior 
compelling the consumer's intention to purchase organic food has received little attention in developing countries. There is limited knowledge concerning the factors that impact consumer's intention to purchase organic food in these countries. The findings in this research showed that subjective norms and attitudes were positively correlated, and they significantly impacted the purchase intention of organic food. The findings also showed that knowledge about organic food and health consciousness has an indirect effect on the relationship between attitude, subjective norms, and intention to buy. Troudi and Bouyoucef [33] proposed a model based on reasoned action theory that combines two types of variables, the green marketing type and personal type, in order to predict purchasing behavior of green food. The model was confirmed, and the results showed how green marketing and personal factors influence the green food purchasing behavior in a direct and indirect way, in presence of the mediating variables' attitude toward green food and intention to buy green food. Nair and Shams [34] examined whether food and grocery $(F \& G)$ shoppers in India are strongly influenced by store-attributes. The findings show that store-attributes-atmosphere, promotion, convenience, facilities, merchandise, store personnel interaction, and services affect store choice decisions. Wang et al. [35] associated intention to buy organic food with knowledge. Findings show that knowledge positively moderates the relationship among subjective norms, personal attitude, health consciousness, and organic food purchase intention.

Frewer et al. [36] concluded that the research of the requirements and attitudes of citizens-potential consumers-in the countries of the European Union, which was conducted between 1989 and 2000, can be summarized as follows:

- Citizens generally accept the use of mechanized tillage methods better than the use of chemicals;

- Old, known tillage and livestock technologies are more accepted than new, automated ones;

- Conventional reproduction in plant and livestock production is much more desirable than reproduction with the use of genetic modifications;

- Natural methods in food processing are more accepted than modernized, so-called hi-tech food industry.

On the other hand, certain authors had a different approach, analyzing the influence of the state, its regulations, and regulations in the field of organic production on the very decisions of consumers to purchase organic products. Vadnal [37], in the mid-1990s, researched the influence of the state in the field of "healthy" food in accordance with the increasingly pronounced demands of citizens to define the difference between health and food produced in the usual (conventional) way. Efforts seem to be made to adequately regulate this issue, which is obviously very interesting for citizens, as well as for potential producers. During this period, the first legal regulations in the field of production, which began to be called organic agriculture, began to be passed [20]. Regulations in the field of the right to certification and penal provisions are also adopted in cases of non-compliance with the provisions of the law. Over time, national legislation becomes uniform for all EU member states, with each country still striving to develop its own national logo. At the same time, there are major changes in the field of marketing, which begins to respect the desire of consumers to be accurately informed, and marketing efforts are focused on highlighting the benefits of products based on the certificate, and adopting a number of new features of health food marketing. In their work, Grunert and Juhl [38] presented the first regulations regarding the labeling of health-safe food in the European Union dating back to 1990. As the public's interest in the link between diet and health increases, efforts are intensifying to improve regulations in this area and to harmonize as much as possible in all member states. The same authors [38] presented the results of research with Danish school teachers regarding their values, attitudes on environmental protection, and the purchase of organic food. The aim was to examine the applicability of value theory and approach measurement in explaining specific aspects of consumer behavior. They conducted two large studies which indicate that health-safe food has acquired a niche market dimension, 
and the most important role in consumers' decision to buy is availability, trust, and an adequate price level [39]. Yang et al. [40] stated that general confusion is exacerbated by the fact that consumers (as confirmed by a large number of studies) are largely insufficiently acquainted with the essence of environmentally friendly food, with the methods of production, processing, certification, and control. On the other hand, even when they are offered additional information that should indicate, for example, the proper use and treatment of food, the vast majority of consumers do not notice such instructions on the product at all (as many as 95\%), and from those who see additional instructions, 79\% of them did their best to read and reread the notice. Therefore, in most European Union countries, as part of programs for the affirmation of environmental suitability and eco-marketing, the process of educating the population is given special attention.

\section{Materials and Methods}

The empirical research of the organic food market consisted of gathering data through a survey in the form of face-to-face interviews, with interviewers recording respondents' answers to a list of questions in a questionnaire. The largest amount of data was collected directly through conversations with respondents, partly in health food stores, farmers' markets, and partly in front of large supermarket chains. The authors oversaw conducting interviews at the mentioned locations. Respondents who showed interest in organic products in stores were approached by the authors with the question of whether they could set aside a few minutes of their time to help research the organic market. In front of large markets, the authors approached a larger number of respondents with the question of whether they had heard or whether they used organic products. If the answer was yes, they asked the above question and approached the interview in case of a positive answer.

The research was conducted in Novi Sad and Belgrade in late 2015 and early 2016. The sample included 496 respondents over 18 years of age, of varying levels of education, and different marital status and other sociodemographic characteristics. The sampling was non-probabilistic, occasional, and volunteer which is by convenience procedure.

The questionnaire created for this research relies significantly on experiences of researchers from other countries such as Great Britain, Denmark, Germany, USA; Croatia, Italy, Switzerland, Sweden, Australia, and others [5,24,25,28,41-47]. Papers used in this study come predominantly from reputable international scholarly journals.

The questionnaire consisted of 18 (groups of) questions about respondents' attitudes towards factors which influence their decision of whether to purchase food products as well as their opinion about most relevant characteristics of food products. Their knowledge of organic products, satisfaction with them, and satisfaction with their offer on the domestic market were also tested with individual questions. When it comes to the type of question in the questionnaire, semi-open-ended questions and (mostly) closed-ended questions are combined with more than two offered answers, and only one open-ended question. In addition, five questions were formulated in the form of the Likert scale, where number one expressed complete disagreement and number five completely agreed with the stated statement, i.e., attitude. As already mentioned, when compiling the questionnaire, previous research was used, i.e., the results obtained in the same, as well as certain attitudes used in these surveys in order to find out the attitudes of respondents when it comes to the market and consumption of organic food products in Serbia. In addition to the 18 questions, the questionnaire included questions about the respondents' sociodemographic characteristics such as: sex, age, marital status, education, employment status, the number of household members, and the total monthly income of the household. The complete questionnaire is included in the Supplementary.

One of the methods used to analyze data collected in the empirical research of the organic market in Serbia was cluster analysis, which segmented respondents into three mutually heterogeneous clusters according to following factors:

- Factors which influence respondents' food purchase in general;

- Factors pertaining to products' characteristics; 
- Factors pertaining to respondents' food consumption habits; and

- Sociodemographic characteristics.

Keeping in mind the volume of data, the paper presents only an excerpt of the second question, which served as a basis for conducting cluster analysis and, as already mentioned, a complete survey is available in the Supplementary. Cluster analysis was applied to the second question in the questionnaire. The second group of questions was about discovering consumers' habits and their attitude towards certain statements (Table 1).

Table 1. An extract from the questionnaire from the second group of questions.

\begin{tabular}{|c|c|c|c|c|c|c|}
\hline \multicolumn{7}{|c|}{ On the Scale from 1 to 5, Indicate to What Extent You Agree with the Following Statements * } \\
\hline 1 & I consume healthy food products; I care about what gets into my body & 1 & 2 & 3 & 4 & 5 \\
\hline 2 & Imported food products are of better quality & 1 & 2 & 3 & 4 & 5 \\
\hline 3 & I am careful about the energy value (calories) and fat which I consume & 1 & 2 & 3 & 4 & 5 \\
\hline 4 & I prefer buying food products produced in Serbia & 1 & 2 & 3 & 4 & 5 \\
\hline 5 & Packaging plays a significant role when I buy food & 1 & 2 & 3 & 4 & 5 \\
\hline 6 & My diet consists mainly of fresh produce & 1 & 2 & 3 & 4 & 5 \\
\hline 7 & I try to be informed about healthy lifestyles & 1 & 2 & 3 & 4 & 5 \\
\hline 8 & I habitually consume fast food & 1 & 2 & 3 & 4 & 5 \\
\hline 9 & $\begin{array}{l}\text { Conservation of nature and living in accordance with nature are } \\
\text { important to me }\end{array}$ & 1 & 2 & 3 & 4 & 5 \\
\hline
\end{tabular}

* 1—strongly disagree; 2—disagree; 3-I do not know; 4—agree; 5—strongly agree.

The results of processing these questions are first presented (in the Results section) through descriptive statistics (simple frequency distributions). In the later presentation of the results, the results of the cluster analysis are presented, which, with the help of these questions, gave answers about the basic clusters, i.e., they could be called "consumer profiles" in relation to organic food products. F statistics for cluster analysis purposes, mean values for variables within a cluster, analysis of the variance of the first question, i.e., the factors that generally influence the decision of the respondents when buying food products and distribution of respondents by clusters based on socio- demographic characteristics, are attached in the Supplementary.

\section{Results and Discussion}

In this part of the paper, the research results will be presented through descriptive statistics (simple frequency distributions). The next step was factor analysis, to determine the components that most influence the decision of the respondents when buying food products. For this purpose, it was first checked whether it was possible to perform a factor analysis on the collected data, and therefore the Kaiser-Meyer-Olkin test (KMO test) and the Bartlett test were performed. Given that the value of the KMO coefficient was greater than 0.6, and the significance of Bartlett was less than 0.05, it was concluded that it is possible to perform a factor analysis. In the later presentation of the results, the result of the cluster analysis will be presented, which, with the help of the second block of questions, gave answers about the consumers tendencies when buying organic produce. The second block of questions was aimed at discovering consumers' buying habits as well as their opinions on certain issues (as evidenced by the given extract from the questionnaire). In addition to conducting cluster analysis, it is important to recognize what governs consumers' purchasing behavior and could therefore be relevant for organic products and their manufacturers.

\subsection{Consumers Buying Habits}

Replying to the question to what extent they agree with the statement that they consume "healthy" food products and that they care about what gets into their body, over $68 \%$ of the respondents replied either that they agree or strongly agree with the statement. 
Due to the fact that there is a great number of food products imported into Serbia from abroad, it is important to discover to what extent the respondents from the analyzed sample agree with the statement that foreign products are of higher quality. The results show that $38.67 \%$ of respondents either strongly disagree or disagree with that statement, which is somewhat greater than the percentage of those who either agree or strongly agree $(34.82 \%)$. There is a significant portion of those respondents who do not know, that is, those who are undecided. These percentages testify of a certain degree of trust that Serbian consumers have in local food producers [1]. Further analysis of the obtained results indicates that there is a statistically significant dependence $(p=0.049)$ of the marital status of the respondents and the attitude that foreign, imported food products are of better quality. Unmarried respondents mostly agree that foreign, imported food products are of better quality, while widows agree the least with this attitude. Regarding the quality of food products, the analysis showed that the students most agree with the attitude that foreign, imported food products are of better quality than domestic ones. Correlation analysis of these obtained answers showed that older respondents are less likely to believe that foreign, imported food products are of better quality (correlation coefficient $r=-0.144$, $p=0.001$ ).

Regarding respondents' eating habits, the aim was to discover to what degree they look after their health by consuming the optimal number of calories and amount of fat. The results show that the number of respondents who do not have such habits is larger than the number of respondents who do (Figure 1).

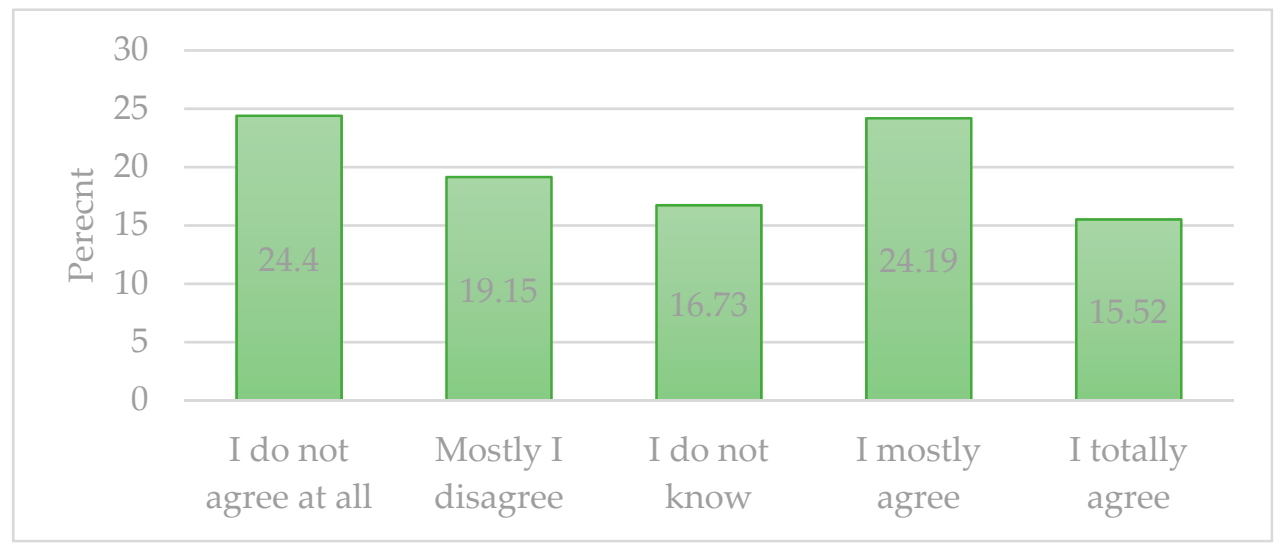

Figure 1. Results showing agreement with the statement "I am careful about the energy value (calories) and fat which I consume".

As in the previously discussed result, a significant percentage of respondents from the sample either agree or strongly agree with the statement that they prefer buying food products produced in Serbia (57.78\%). This result, together with the result of the question about buying imported food products, speaks to the fact that the respondents prefer buying products made in Serbia to products imported from foreign countries, which is particularly important for organic food products which are the subject of this research (Figure 2). Correlation analysis shows that as the education level of respondents increases, the likelihood of them buying food products from Serbia decreases (the correlation coefficient $\mathrm{r}=-0.144$ ). Furthermore, the older the respondents, the more likely they are to buy Serbian food products [48] (the correlation coefficient $r=0.164$ ). Thus, the analysis shows that retirees are more likely to buy Serbian products. However, the higher the income of the respondents, the less significant this factor becomes, meaning that people with higher income are less likely to buy Serbian food products (the correlation coefficient $r=-0.125$ ). 


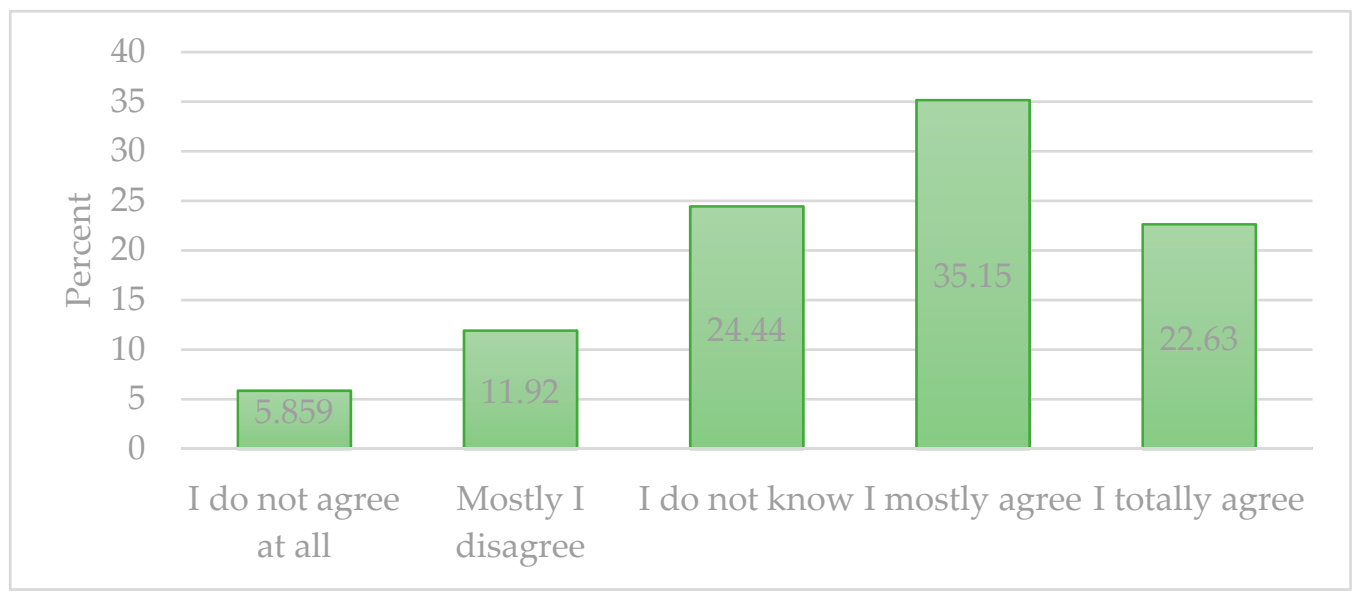

Figure 2. Results showing agreement with the statement "I prefer buying food products from Serbia".

Significant findings came from the analysis of the respondents' responsesto the question about the role packaging plays in decisions governing food purchase (Figure 3). For different reasons, packaging has turned out to be an important factor which influences the purchase of food products. As shown in Figure 3, only 33.87\% of the respondents either strongly disagree or disagree with the statement while almost half of the respondents think packaging is an important factor in buying food products (48.59\%). No statistically significant correlations were shown between this factor and other variables.

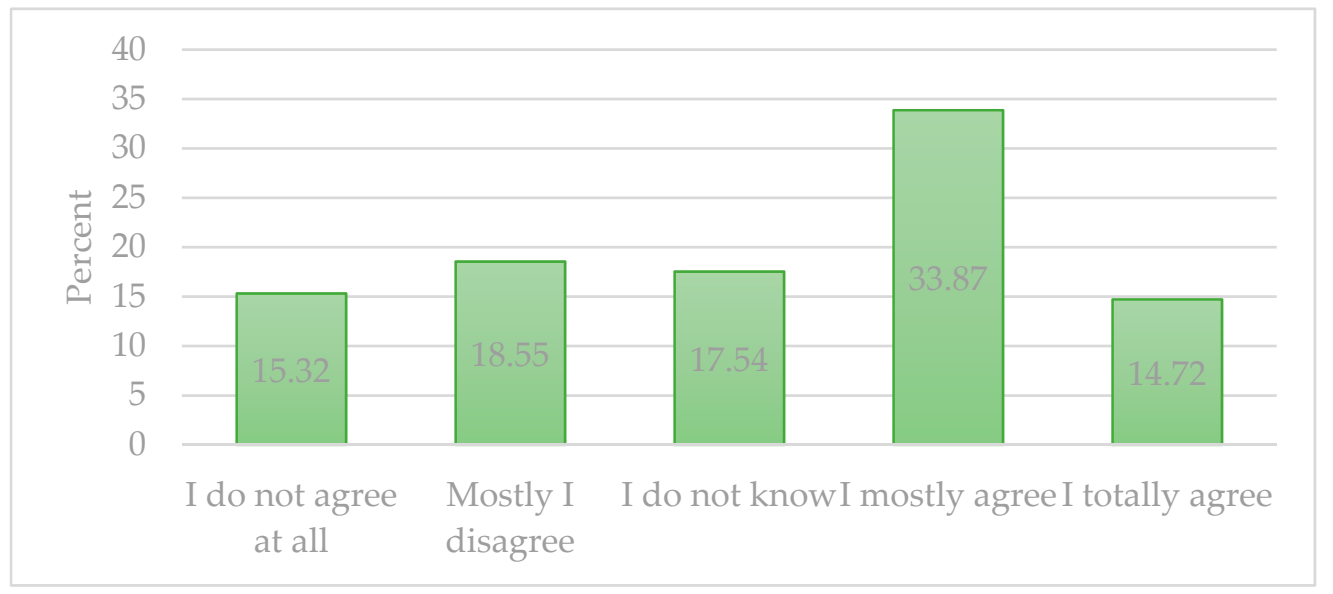

Figure 3. Results showing agreement with the statement "Packaging plays a significant role when I buy food".

The majority of respondents mainly eat fresh produce, which is important when it comes to food consumption, that is, consumption of food products available in the Serbian market where both supply and demand include predominantly fruits and vegetables and much less other types of organic food products (Figure 4). There is a statistically significant correlation between education and the intention to eat fresh produce (the correlation coefficient $r=0.104$ ). At the same time, as the respondents' age increases, their habit of consuming fresh produce decreases, but that correlation is weak (the correlation coefficient $\mathrm{r}=-0.090)$. 


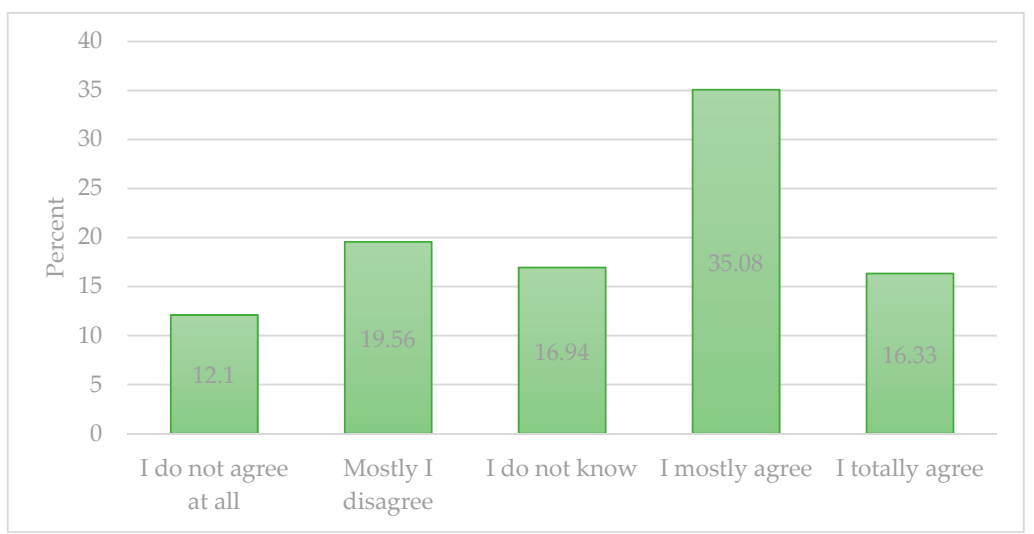

Figure 4. Results showing agreement with the statement "My diet consists mainly of fresh produce".

The research into the respondents' purchase of food products, their eating habits, and lifestyles needs to discover to what extent the respondents are informed about healthy lifestyles and to what extent they eat the so-called "fast food", the consumption of which is noticeably increasing (Figures 5 and 6). The results show a correlation between responses to these two questions, meaning that the majority of respondents from the analyzed sample makes efforts to be informed about healthy lifestyles $(61 \%)$ while a small percentage habitually eat so-called "fast food" $(27.6 \%)$. Correlation analysis shows that the higher the income, the more likely the respondents are to be informed about healthy lifestyles, but the correlation is weak (the correlation coefficient $r=0.075$ ). The same is true of education, meaning that the higher the education, the more likely the respondents are to pay attention to healthy lifestyles (the correlation coefficient $r=0.110$ ). Regarding "fast food" consumption, the analysis shows that single respondents are more likely to consume "fast food", and that the older the respondents, the less likely they are to consume "fast food" (the correlation coefficient $r=-243$ ). Accordingly, retirees are the least likely and students are the most likely to consume "fast food." Considering the respondents' sex, the analysis shows that men are more prone to this habit than women.

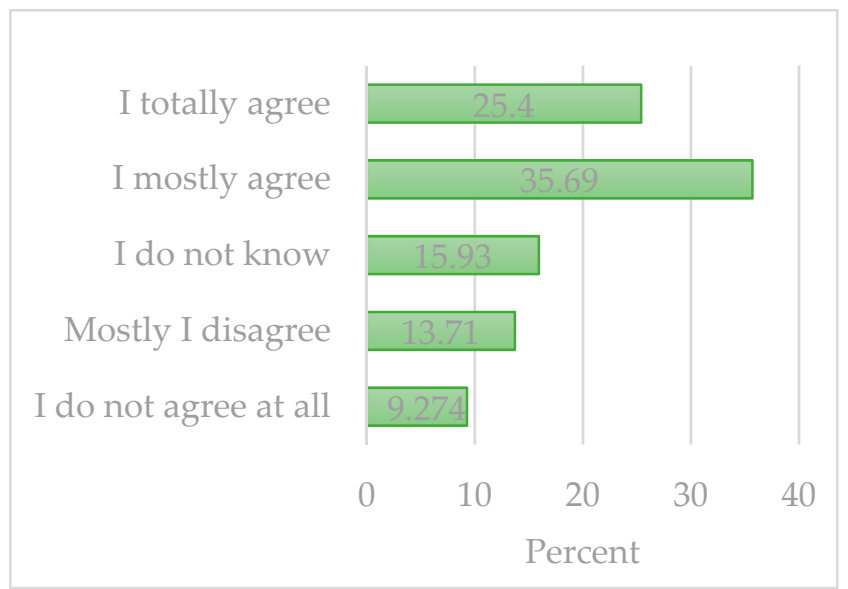

Figure 5. How informed the respondents are about healthy lifestyles and healthy eating. 


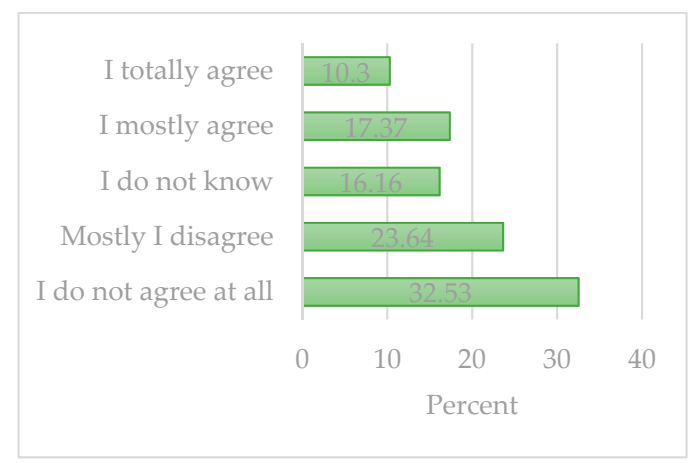

Figure 6. How informed the respondents are about healthy lifestyles and healthy eating.

It was important in this study to discover the respondents' opinion about the significance of conservation of nature and living in accordance with nature (Figure 7). A small percentage of respondents in the sample either strongly disagree or disagree with this statement (about $26 \%$ ) while the percentage of those who agree with the statement is almost twice as large $(53.43 \%)$. Correlation analysis shows that people with a higher level of education are more likely to hold this view, but the correlation is weak (the correlation coefficient $\mathrm{r}=0.079$ ). In addition, older people are more likely to hold this view (the correlation coefficient $r=0.090$ ) as well as people with higher income, but the correlation is weak (the correlation coefficient $r=0.075$ ).

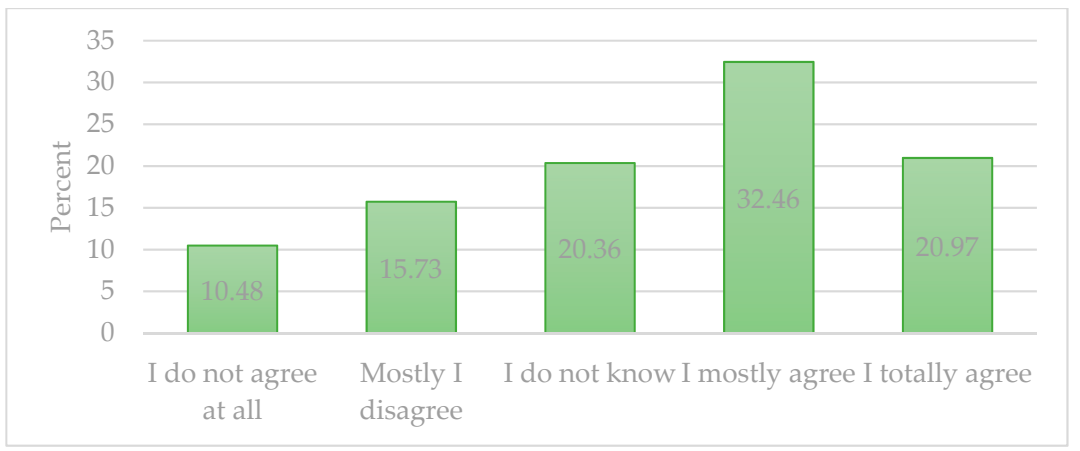

Figure 7. Results showing agreement with the statement "Conservation of nature and living in accordance with nature are very important to me".

\subsection{Factor Analysis}

In the next step, a factor analysis was performed to determine the components that most influence the decision of the respondents when buying organic food products. First, it is necessary to check whether it is possible to do a factor analysis on these data, and therefore, a $\mathrm{KMO}$ and Bartlett test were performed. Given that the value of the KMO coefficient is greater than 0.6, and the significance of Bartlett is less than 0.05 , it is possible to perform a factor analysis. Then, the factor analysis of the first question was done. The column contains the factors, 14 of them, because analysis was done on the first question (first question and complete survey is in Supplementary). For a factor to be significant, it must have a value greater than or equal to 1, and these values are read from the column Initial value-Total. Based on that, it is concluded that 4 components/factors were obtained that explain $56 \%$ of the variations of the observed variables. This percentage can be seen in the column Initial value-Cumulative $\%$. This analysis shows the statistical equality of the observed values based on the following assumptions: (1) The choice of respondents in groups should be random and independent, (2) The variability of results in the populations of the analyzed groups should be statistically equal, (3) The results of groups should be normal distributed, i.e., not to deviate statistically significantly from the normal distribution. Data are shown in Table 2. 
Table 2. KMO (Kaiser-Meyer-Olkin) and Bartlett's test, data related to analysis of variance (software excerpt), and data related to pattern matrix analysis *.

\begin{tabular}{|c|c|c|c|c|c|c|c|}
\hline \multicolumn{4}{|c|}{ Description } & \multicolumn{4}{|c|}{ Data } \\
\hline \multicolumn{4}{|c|}{ Kaiser-Meyer-Olkin Measure of Sampling Adequacy } & \multicolumn{4}{|c|}{0.756} \\
\hline \multirow{3}{*}{$\begin{array}{l}\text { Bartlett's Test } \\
\text { of Sphericity }\end{array}$} & Approx. C & & & \multicolumn{4}{|c|}{1425.032} \\
\hline & & & & & & 0.91 & \\
\hline & Sig. & & & & & 0 & \\
\hline \multirow{2}{*}{ Component } & \multicolumn{3}{|c|}{ Initial value } & \multicolumn{3}{|c|}{ The sum of squares loading } & \multirow{2}{*}{$\begin{array}{l}\text { Rotation sums of } \\
\text { squares loadings }\end{array}$} \\
\hline & Total & Variance & Cumulative & Total & Variance & Cumulative & \\
\hline 1 & 3.455 & 24.676 & 24.676 & 3.455 & 24.676 & 24.676 & 2.444 \\
\hline 2 & 1.792 & 12.801 & 37.477 & 1.792 & 12.801 & 37.477 & 2.509 \\
\hline 3 & 1.54 & 11.003 & 48.48 & 1.54 & 11.003 & 48.48 & 1.487 \\
\hline 4 & 1.058 & 7.559 & 56.039 & 1.058 & 7.559 & 56.039 & 2.157 \\
\hline 5 & 0.946 & 6.761 & 62.8 & & & & \\
\hline 6 & 0.783 & 5.596 & 68.396 & & & & \\
\hline 7 & 0.735 & 5.247 & 73.644 & & & & \\
\hline 8 & 0.682 & 4.873 & 78.516 & & & & \\
\hline 9 & 0.661 & 4.722 & 83.238 & & & & \\
\hline 10 & 0.577 & 4.125 & 87.363 & & & & \\
\hline 11 & 0.518 & 3.702 & 91.065 & & & & \\
\hline 12 & 0.472 & 3.373 & 94.438 & & & & \\
\hline 13 & 0.42 & 2.997 & 97.435 & & & & \\
\hline 14 & 0.359 & 2.565 & 100 & & & & \\
\hline \multirow{2}{*}{\multicolumn{4}{|c|}{ Question }} & \multicolumn{4}{|c|}{ Component } \\
\hline & & & & 1 & 2 & 3 & 4 \\
\hline \multicolumn{4}{|c|}{$\begin{array}{l}1.8 \text { On a scale of } 1 \text { to } 5 \text {, rate how much the product advertisement } \\
\text { affects your decision when buying food products. }\end{array}$} & 0.814 & & & \\
\hline \multicolumn{4}{|c|}{$\begin{array}{l}1.9 \text { On a scale of } 1 \text { to } 5 \text {, rate the fact that the manufacturer is } \\
\text { knowninfluences your decision when buying food products. }\end{array}$} & 0.697 & & & \\
\hline \multicolumn{4}{|c|}{$\begin{array}{l}\text { 1.7 On a scale of } 1 \text { to } 5 \text {, rate how much recommendations (friends, } \\
\text { experts, nutritionist, doctor) influence your decision when buying } \\
\text { food products. }\end{array}$} & 0.636 & & & \\
\hline \multicolumn{4}{|c|}{$\begin{array}{l}1.10 \text { On a scale of } 1 \text { to } 5 \text {, evaluate how clearly written the } \\
\text { composition of the packaging influences your decision when } \\
\text { buying food product. }\end{array}$} & & 0.77 & & \\
\hline \multicolumn{4}{|c|}{$\begin{array}{l}\text { 1.4 On a scale of } 1 \text { to } 5 \text {, evaluate how much the product does not } \\
\text { contain additives and harmful substances affects your purchase } \\
\text { decision food products. }\end{array}$} & & 0.706 & & \\
\hline \multicolumn{4}{|c|}{$\begin{array}{l}1.5 \text { On a scale of } 1 \text { to } 5 \text {, assess how clearly indicated the shelf life of } \\
\text { the product influences your decision when buying food products. }\end{array}$} & & 0.663 & & \\
\hline \multicolumn{4}{|c|}{$\begin{array}{l}1.13 \text { On a scale of } 1 \text { to } 5 \text {, rate the fact that the product is } \\
\text { environmentally friendly (bio) influences your decision when } \\
\text { buying food products. }\end{array}$} & & 0.505 & & \\
\hline \multicolumn{4}{|c|}{$\begin{array}{l}1.6 \text { On a scale of } 1 \text { to } 5 \text {, evaluate how much the favorable price of } \\
\text { the product affects your decision when buying food. }\end{array}$} & & & 0.827 & \\
\hline \multicolumn{4}{|c|}{$\begin{array}{l}1.14 \text { On a scale of } 1 \text { to } 5 \text {, rate the best value for money the product } \\
\text { influences your decision when buying food products. }\end{array}$} & & & 0.786 & \\
\hline \multicolumn{4}{|c|}{$\begin{array}{l}\text { 1.12 On a scale of } 1 \text { to } 5 \text {, rate the fact that the product looks nice } \\
\text { influences your decision when buying food products. }\end{array}$} & & & & 0.788 \\
\hline \multicolumn{4}{|c|}{$\begin{array}{l}\text { 1.11 On a scale of } 1 \text { to } 5 \text {, rate how pleasant the environment in } \\
\text { which the product is sold influences your decision when buying } \\
\text { food products. }\end{array}$} & & & & 0.63 \\
\hline
\end{tabular}


A problem arose here, because each component should contain at least 3 factors, and here that is not the case, i.e., component three contains only two factors. Based on that, it was concluded that the number of components should be reduced to 3 . When the number of components was changed, a new table was obtained (Table 3).

Table 3. Data related to analysis of variance II *.

\begin{tabular}{|c|c|c|c|c|c|c|c|}
\hline \multirow{2}{*}{ Component } & \multicolumn{3}{|c|}{ Initial Value } & \multicolumn{3}{|c|}{ The Sum of Squares Loading } & \multirow{2}{*}{$\begin{array}{l}\text { Rotation Sums of } \\
\text { Squares Loadings }\end{array}$} \\
\hline & Total & Variance & Cumulative & Total & Variance & Cumulative & \\
\hline 1 & 3.455 & 24.676 & 24.676 & 3.455 & 24.676 & 24.676 & 2.978 \\
\hline 2 & 1.792 & 12.801 & 37.477 & 1.792 & 12.801 & 37.477 & 2.648 \\
\hline 3 & 1.540 & 11.003 & 48.480 & 1.540 & 11.003 & 48.480 & 1.606 \\
\hline 4 & 1.058 & 7.559 & 56.039 & & & & \\
\hline 5 & 0.946 & 6.761 & 62.800 & & & & \\
\hline 6 & 0.783 & 5.596 & 68.396 & & & & \\
\hline 7 & 0.735 & 5.247 & 73.644 & & & & \\
\hline 8 & 0.682 & 4.873 & 78.516 & & & & \\
\hline 9 & 0.661 & 4.722 & 83.238 & & & & \\
\hline 10 & 0.577 & 4.125 & 87.363 & & & & \\
\hline 11 & 0.518 & 3.702 & 91.065 & & & & \\
\hline 12 & 0.472 & 3.373 & 94.438 & & & & \\
\hline 13 & 0.420 & 2.997 & 97.435 & & & & \\
\hline 14 & 0.359 & 2.565 & 100.000 & & & & \\
\hline
\end{tabular}

* author's research.

Based on the following table (Table 4), three components were obtained that explain $48.5 \%$ of the variations of the observed variables. Based on the second (new) pattern matrix table, it is possible to conclude that each component has more than two factors.

Table 4. Data related to the analysis of the II pattern matrix (excerpt from the software) *.

\begin{tabular}{|c|c|c|c|c|}
\hline \multirow{2}{*}{ Question } & \multicolumn{4}{|c|}{ Component } \\
\hline & 1 & 2 & 3 & 4 \\
\hline $\begin{array}{l}1.8 \text { On a scale of } 1 \text { to } 5 \text {, rate how much the product advertisement affects } \\
\text { your decision when buying food products. }\end{array}$ & 0.780 & & & \\
\hline $\begin{array}{l}\text { 1.3 On a scale of } 1 \text { to } 5 \text {, evaluate how attractive the product packaging is on } \\
\text { your decision when buying food products. }\end{array}$ & 0.737 & & & \\
\hline $\begin{array}{l}1.9 \text { On a scale of } 1 \text { to } 5 \text {, rate the fact that the manufacturer is known } \\
\text { influences your decision when buying food products. }\end{array}$ & 0.710 & & & \\
\hline $\begin{array}{l}1.11 \text { On a scale of } 1 \text { to } 5 \text {, rate how pleasant the environment in which the } \\
\text { product is sold influences your decision when buying food products. }\end{array}$ & 0.657 & & & \\
\hline $\begin{array}{l}\text { 1.12 On a scale of } 1 \text { to } 5 \text {, rate the fact that the product looks nice influences } \\
\text { your decision when buying food products. }\end{array}$ & 0.594 & & & \\
\hline $\begin{array}{l}1.10 \text { On a scale of } 1 \text { to } 5 \text {, evaluate how clearly written the composition of the } \\
\text { packaging influences your decision when buying food product. }\end{array}$ & & 0.764 & & \\
\hline $\begin{array}{l}\text { 1.4 On a scale of } 1 \text { to } 5 \text {, evaluate how much the product does not contain } \\
\text { additives and harmful substances affects your purchase decision }\end{array}$ & & 0.754 & & \\
\hline $\begin{array}{l}\text { additives and harmful substances affects your purchase decision } \\
\text { food products. }\end{array}$ & & 0.754 & & \\
\hline $\begin{array}{l}1.5 \text { On a scale of } 1 \text { to } 5 \text {, assess how clearly indicated the shelf life of the } \\
\text { product influences your decision when buying food products. }\end{array}$ & & 0.636 & & \\
\hline $\begin{array}{l}1.2 \text { On a scale of } 1 \text { to } 5 \text {, assess how much the origin of the product affects } \\
\text { your decision when buying food products. }\end{array}$ & 0.302 & 0.521 & & \\
\hline $\begin{array}{l}1.13 \text { On a scale of } 1 \text { to } 5 \text {, rate the fact that the product is environmentally } \\
\text { friendly (bio) influences your decision when buying food products. }\end{array}$ & & 0.511 & & \\
\hline $\begin{array}{l}1.1 \text { On a scale of } 1 \text { to } 5 \text {, evaluate how much the quality of the product } \\
\text { affects your decision when buying food products. }\end{array}$ & & 0.464 & & \\
\hline $\begin{array}{l}1.14 \text { On a scale of } 1 \text { to } 5 \text {, rate the best value for money the product } \\
\text { influences your decision when buying food products. }\end{array}$ & & & 0.757 & \\
\hline
\end{tabular}


Table 4. Cont

\begin{tabular}{|c|c|c|c|c|}
\hline \multirow{2}{*}{ Question } & \multicolumn{4}{|c|}{ Component } \\
\hline & 1 & 2 & 3 & 4 \\
\hline $\begin{array}{l}\text { 1.6 On a scale of } 1 \text { to } 5 \text {, evaluate how much the favorable price of the } \\
\text { product affects your decision when buying food. } \\
1.7 \text { On a scale of } 1 \text { to } 5 \text {, rate how much recommendations (friends, experts, } \\
\text { nutritionist, doctor) influence your decision when buying } \\
\text { food products. }\end{array}$ & 0.319 & & 0.755 & \\
\hline
\end{tabular}

* author's research.

Each component is characterized by certain factors, based on which components are defined, with the factors that have the highest value in each component, best reflect the characteristics of a given component. Based on the same table, it is possible to determine the following components:

Component 1: AESTHETICALLY PLEASING AND EASILY RECOGNIZABLE PRODUCT: The product is advertised, of attractive packaging. The manufacturer is well known, it is sold in a pleasant ambience and it looks nice.

Component 2: HEALTHY AND SAFE PRODUCT: The composition of the product and shelf life are clearly indicated, it does not contain additives, it is environmentally friendly and high quality.

Component 3: CHEAP PRODUCT: The product is affordable, characterized by the best price-quality ratio and is recommended by friends, experts, nutritionists, doctors.

\subsection{Cluster Analysis}

After factor analysis cluster analysis, dividing the respondents into heterogeneous clusters according to three criteria followed: factors which generally influence their food purchasing decisions, their opinions regarding characteristics of food products and their eating habits, and their sociodemographic characteristics (All values of this calculation are given in the Supplementary).

The sample was divided into 3 clusters which were internally homogenous yet mutually heterogeneous. The clusters were formed after 13 iterations (Table 5). This method resulted in clusters with the values as shown in Table 5.

Table 5. Iterative partitioning method of the first cluster analysis.

\begin{tabular}{cccc}
\hline \multirow{2}{*}{ Iterations } & \multicolumn{3}{c}{ Variations between Cluster Means * } \\
\cline { 2 - 4 } & $\mathbf{1}$ & $\mathbf{2}$ & $\mathbf{3}$ \\
\hline 1 & 2.948 & 3.282 & 3.266 \\
2 & 0.295 & 0.303 & 0.315 \\
3 & 0.101 & 0.115 & 0.167 \\
4 & 0.054 & 0.077 & 0.088 \\
5 & 0.053 & 0.036 & 0.095 \\
6 & 0.031 & 0.079 & 0.096 \\
7 & 0.023 & 0.108 & 0.107 \\
8 & 0.032 & 0.119 & 0.154 \\
9 & 0.065 & 0.110 & 0.160 \\
10 & 0.060 & 0.080 & 0.116 \\
11 & 0.039 & 0.033 & 0.073 \\
12 & 0.026 & 0.000 & 0.033 \\
13 & 0.000 & .0000 & 0.000 \\
\hline
\end{tabular}

* author's calculation.

As shown in Table 6, the first cluster is the largest while the second is the smallest. To describe the clusters, the F-statistic was used to determine which variables were the most relevant for partitioning. First, the F-statistic was applied to the second question. Values of the F-statistic show that three variables which have the highest values are at the same time the variables which are the most significant for partitioning, and they are in order of significance: 
2.7. I try to be informed about healthy lifestyles.

2.1. I consume healthy food products; I care about what gets into my body.

2.3. I am careful about the energy value (calories) and fat which I consume.

Table 6. Clusters after the first cluster analysis *.

\begin{tabular}{|c|c|c|}
\hline Description & Number of Clusters & Number of Respondents \\
\hline \multirow{3}{*}{ Cluster } & 1 & 204.000 \\
\hline & 2 & 134.000 \\
\hline & 3 & 155.000 \\
\hline \multicolumn{2}{|c|}{ Valid } & 493.000 \\
\hline \multicolumn{2}{|c|}{ Not valid } & 3.000 \\
\hline
\end{tabular}

* author's calculation.

Variables with the lowest F-value are those which have the least influence on the formation of the clusters, and they are as follows (2.4 variable has the least influence of the three):

2.5. Packaging plays a significant role when I buy food.

2.8. I habitually consume fast food.

2.4. I prefer buying food products produced in Serbia.

To confirm the results, comparisons were made between mean values of all variables within each cluster through LSD (Least Significant Difference) test (in Supplementary).

The analysis showed that differences are largest between the arithmetic means of variables 1,3 , and 7 , while differences are smallest between variables 4,5 , and 8 , confirming the results of our study. This led to the exclusion of variables $2.4,2.5$, and 2.8 from the following stage, because they were proven to have the smallest influence. After that, another cluster analysis was carried out with the aim of reaching more homogenous clusters.

The second cluster analysis had 9 iterations (Table 7). Based on this procedure, clusters with the following values were formed (Table 8).

Table 7. Iteration procedure for the purpose of the second cluster analysis *

\begin{tabular}{cccc}
\hline \multirow{2}{*}{ Iterations } & \multicolumn{3}{c}{ Variations between Cluster Means } \\
\cline { 2 - 4 } & $\mathbf{1}$ & $\mathbf{2}$ & $\mathbf{3}$ \\
\hline 1 & 2.388 & 2.200 & 2.331 \\
2 & 0.267 & 0.232 & 0.399 \\
3 & 0.121 & 0.135 & 0.243 \\
4 & 0.076 & 0.093 & 0.133 \\
5 & 0.092 & 0.061 & 0.130 \\
6 & 0.032 & 0.049 & 0.077 \\
7 & 0.017 & 0.034 & 0.055 \\
8 & 0.017 & 0.000 & 0.011 \\
9 & 0.000 & 0.000 & 0.000 \\
\hline
\end{tabular}

* author's calculation. 
Table 8. Clusters after the second cluster analysis *

\begin{tabular}{|c|c|c|}
\hline Description & Number of Clusters & Number of Respondents \\
\hline \multirow{3}{*}{ Cluster } & 1 & 105.000 \\
\hline & 2 & 222.000 \\
\hline & 3 & 167.000 \\
\hline \multicolumn{2}{|c|}{ Valid } & 494.000 \\
\hline \multicolumn{2}{|c|}{ Not valid } & 2.000 \\
\hline
\end{tabular}

* author's calculation.

Cluster structure is much more homogenous in this instance. However, the size of clusters has changed, too. The largest cluster now is the second one, and the smallest is the first one. In order to compare arithmetic means of different clusters, analysis of variance was used.

The results show that there is a statistically significant difference in every variable between arithmetic means of the clusters. This can be seen in the Sig column in the table, where all values are lower than 0.05 , bearing in mind that variables $2.4,2.5$, and 2.8 were excluded from the analysis because they lower homogeneity of the cluster.

Every statistically significant result is marked by an asterisk $\left(^{*}\right)$ next to the number in the mean difference (I-J). The cluster in column I is compared with each cluster in column J individually, with respect to every variable, and the result is statistically relevant if the Sig in the row of cluster $\mathrm{J}$ is lower than 0.05

In the next step, an analysis of variance was applied to the first question, that is, the question regarding factors which generally influence food purchasing decisions of respondents. As it turned out, the factor of "Good quality and value for money" did not play a part in the distribution of respondents into clusters, meaning that there was no statistically significant difference between clusters with regard to this factor.

After that, the respondents were distributed into clusters according to their sociodemographic characteristics and it turned out that there was no statistically significant difference between clusters with regard to: sex, number of children, employment status, and total monthly income of the household. That means that there was a statistically significant difference between clusters regarding: age, marital status, number of household members, education, and occupation $[49,50]$.

To define clusters more easily, mean plots were used in this analysis. Based on all analyses conducted in this study, the following groups (i.e., clusters) and their characteristics have emerged:

Cluster 1:

This group consists mainly of respondents who are over 35 years of age, single or married, have one household member and a lower level of education, and are tradesmen or blue-collar workers. What they consider of least importance is whether they consume "healthy" products and what the energy value of those products is. When purchasing food items, they pay least attention to whether the products are organic or not. Nor is a clearly marked expiration date of much importance to this group, and this constitutes the largest difference between this cluster and the other two clusters. In addition, they do not assign any importance to the origin of products, packaging, or pleasantness of setting in which the product is sold. When buying food items, respondents in this cluster pay attention to getting value for money, and the most important factor which influences their decision is product price.

Cluster 2:

This group consists of respondents who are under 45 years of age, with most of them between 25 and 34, single or married, (but this cluster has a higher number of divorced people than either Cluster 1 or Cluster 3), and have 2-4 household members. Regarding the level of education, most respondents in this cluster have high school or university education. Their occupations include tradesmen, engineers, and professionals, with the largest number of professionals, that is, people with a university degree. When com- 
pared with other two clusters, respondents in this cluster pay most attention to what they consume, and they want to be informed about healthy lifestyles. Factors which they find important when purchasing food items include quality, recommendation, marketing, renowned manufacturer, product aesthetics, and a pleasant setting in which the product is sold. The importance they assign to these factors puts this group in stark contrast with the other two groups. The least important factor to this group is product origin, but they still assign more importance to it than Clusters 1 and 3. Two most important factors to this group are product quality and a clearly marked expiration date.

Cluster 3:

This group consists of respondents between 25 and 54 years of age, predominantly single or married, with 3 or 4 household members. The level of education of this group is like that of Cluster 2, that is, most respondents in this group have high school or university education. This group is like the previous one regarding occupations, too, but engineers with university degrees are prevalent in this cluster. Respondents in this cluster think that it is important to eat "healthy" food, but they pay less attention to product origin than either Cluster 1 or 2. Regarding factors which influence purchase of food items, it is important to them that the product comes from an organic system of production and has a clearly marked expiration date, and the most important factor is product quality. Respondents in this group do not assign importance either to recommendations and product aesthetics or to the way it is marketed and packaged.

Based on this, it should be noted that combining cluster and factor analysis leads to the following conclusion:

If we look at the relationship between clusters and components that affect food purchases, it can be concluded that:

Cluster 1 corresponds to component 3 (CHEAP PRODUCT).

Cluster 2 corresponds to components 1 and 2 (AESTHETICALLY PLEASING AND EASILY RECOGNISABLE PRODUCT and HEALTHY AND SAFE PRODUCT.

Cluster 3 corresponds to component 2 (HEALTHY AND SAFE PRODUCT).

The abovementioned conclusion is presented in Table 9.

Table 9. Results as divided into clusters *

\footnotetext{
Cluster 1:

This group consists mainly of respondents who are over 35 years of age, single or married, have one household member and a lower level of education, and are tradesmen or blue-collar workers. Of least importance to them is whether they consume healthy products and the number of calories those products have. When purchasing products, it is of least importance to them whether the products are environmentallyfriendly or not. A clearly marked expiration date is an equally insignificant factor, and that constitutes the largest difference between this cluster and the other two clusters. In addition, they do not assign any importance to the origin of products, packaging, or a pleasant setting in which the product is sold. When buying food items, respondents in this cluster pay attention to getting value for money, and the most important factor which influences their decision is product price.
}

\author{
Component 3: \\ CHEAP PRODUCT: \\ The product is \\ reasonably priced or \\ sold at a bargain price; \\ it is good value for \\ money and it is \\ recommended by a \\ friend, expert, \\ nutritionist, doctor.
}


Table 9. Cont.

\begin{abstract}
Cluster 2:
This group consists of respondents who are under 45 years of age, with most of them between 25 and 34, single or married, (but this cluster has a higher number of divorced people than either Cluster 1 or Cluster 3), and have 2-4 household members. Regarding the level of education, most respondents in this cluster have high school or university education. They are mostly tradesmen, engineers, and professionals, with the largest number of professionals. When compared with the other two clusters, respondents in this cluster pay most attention to what they consume and they want to be informed about healthy lifestyles. Factors which they find important when purchasing food items include: quality, recommendation, marketing, renowned manufacturer, aesthetic, and a pleasant setting in which the products is sold. The importance they assign to these factors sets this group starkly apart from Cluster 1 and Cluster 3. The least important factor to this group is product origin, but they still assign more importance to it than Clusters 1 and 3 . The two most important factors to this group are product quality and a clearly marked expiration date.
\end{abstract}

\section{Component 1:} AESTHETICALLY PLEASING AND EASILY RECOGNISABLE PRODUCT:

The product is well-marketed, attractively packaged. It is produced by a renowned manufacturer, sold in a pleasant setting, and looks nice.

\section{Component 2: HEALTHY AND SAFE PRODUCT: Ingredients and the expiration date are clearly stated; the product does not contain additives, it is eco-friendly, and of good quality.}

\footnotetext{
Cluster 3:

This group consists of respondents between 25 and 54 years of age, predominantly single or married, with 3 or 4 household members. Level of education of this group is similar to that of Cluster 2, that is, most respondents in this group have high school or university education. This group is similar to the previous one with regard to occupations, too, but engineers are prevalent in this cluster. Respondents in this cluster think that it is important to eat "healthy" food, but they pay less attention to product origin than either Cluster 1 or 2. Regarding factors which influence purchase of food items, it is important to them that the product is eco-friendly and has a clearly marked expiration date, and the most important factor is product quality. Respondents in this group do not assign importance to recommendations and product aesthetics. This sets them apart from Clusters 1 and 2. In addition, respondents in this cluster do not assign importance to marketing and packaging.
}

\section{Component 2: \\ HEALTHY AND SAFE \\ PRODUCT: \\ Ingredients and the expiration date are clearly stated; the product does not contain additives; it is eco-friendly and of good quality.}

* author's research.

\subsection{Discussion}

As can be seen from the presented research results, the analysis on a random sample from the two largest cities in Serbia, Belgrade, and Novi Sad, showed that consumers of organic products from the analyzed sample can be grouped into three clusters corresponding to certain components related to characteristics products that can be found in the domestic market.

In the research, the education factor showed that most of those with secondary and higher education are in the group of those who care about eating "healthy" food. In addition, the research showed that there is a statistically significant difference between clusters based on: age, marital status, household members, education, and occupation [49].

The mentioned research [28] showed that there is a segmentation of consumers in relation to the variable of organic food consumption in the USA. They were correlated with environmental concerns, knowledge, and health concerns, as well as some demographic characteristics (race, gender, age, education). In contrast, in the research segment marked as "segment 3 -" negligent individuals "were younger respondents with a higher level of education, but who did not show much concern for nutrition, quality, and nutritional value. However, a similar study was shown in the study by Magetts et al. [23], that there is a special emphasis on the influence of the level of education of the respondents on the choice of "healthy" food, where the result showed that it is the factor of the strongest influence. Other research shows that among the surveyed consumers, health care is in the first place, $44 \%$ of respondents stated that it is the most important reason, $15 \%$ emphasize health as an important factor, only $2 \%$ believe that health is not an important factor when buying organic agri-food products [51]. The results of research in several cities in Serbia 
(Belgrade, Novi Sad, Nis, Kragujevac, and Novi Pazar), given by Vehapi [18], also show that health is the most important motive for buying organic food in Serbia. As many as $81.6 \%$ of consumers rated health as the leading motive when ranking. Slightly different influencing factors are given in two studies from Italy that indicate that health-safe food has acquired the dimension of a niche market, and the most important role in consumers' decision to buy it have availability (availability), trust, and an adequate price level [52]. On the other hand, in their research, Canio Francesca and Elisa [53] showed that regional and locally produced food, as well as organic products, are experiencing an increasing success amongst consumers as perceived as authentic high-quality food products, able to contribute to sustainable methods of production and consumption. Applying the theory of reasoned action, this work compares consumers' intention to buy EU quality labels and organic food products. Results revealed different motives at the roots of the two products buying choices. On one hand, shoppers are willing to pay a premium price for sustainable EU quality label foods. On the other hand, recyclable packaging is mandatory to shape the intention to buy organic foods. Ditlevsen et al. [54] elaborated on organic consumers features and established that they were more likely to live in the capital and have a higher education.

\section{Conclusions}

The results of the research showed that organic consumers in Serbia can be grouped into 3 clusters based on certain characteristics and components.

As Table 9 shows, Cluster 1 is rather specific and is characterized by a category of respondents who assign least importance to whether they eat "healthy" products and to the number of calories in those products. When buying food items, they assign least importance to whether the products are organic. Similarly, a clearly marked expiration date is not considered important, which sets this group apart from the other two clusters. When buying food products, this category of respondents pays attention mainly to the price, which leads to the conclusion that these buyers are highly unlikely to consume organic food in the future, partly because those products cost more and partly because of inherent characteristics of these specific products whose eco-friendly features, emphasis on "healthiness" and similar factors clearly have no influence on buyers in this cluster. Respondents in Cluster 2 differ from respondents in other two clusters because they care most about what they consume, and they try to be informed about healthy lifestyles. Regarding factors which relates to purchase of food, they care about: quality, recommendation, marketing, renowned manufacturer, product aesthetics, and pleasantness of setting in which the product is sold. Respondents in Cluster 3 assign importance to eating "healthy" food, and they care less about product origin than either respondents in Cluster 1 or Cluster 2. Regarding factors that are associated with purchase of food products, it is important to them that the product comes from an organic system of production and has a clearly marked expiration date, and the most important factor is product quality.

In such a case, eco-marketing should be more directed towards those consumers who are already "more environmentally and health conscious", which are those in Cluster 2, because evidence demonstrates that respondents who buy organic products are largely attracted to product provenance, an attractive packaging design, an absence of additives and harmful substances, a clearly marked expiration date, a pleasant setting in which the product is sold, and the fact that the product is environmentally friendly. This indicates that it is important for eco-marketing to emphasize these product characteristics to increase their sales and influence the consumers.

Keeping in mind the results of the research, certain measures of economic and agrarian policy should go in the direction of encouraging this form of agricultural production, especially to consumers that can be subsumed under Cluster 1. First, it is necessary to improve consumer knowledge about what organic production is and how products from this production system are properly labeled. This can be achieved through media and other forms of campaigns (in retail outlets) where the promotion of organic products would be 
carried out continuously and at the same time with education of consumers. In addition, education within primary and secondary schools can improve the state of organic demand in the domestic market in the long run. Promotions of organic products at certain events (Organic Street of Novi Sad, etc.) contribute to raising the visibility of this system of production and local self-government, by supporting such events; contributes to raising environmental awareness among consumers.

The main limitation of this study is related to both the convenient sample and the limited geographical area. It is reflected in the fact that only the markets of Belgrade and Novi Sad are covered. Although these are currently the largest and most significant domestic markets for organic products, further research should go in the direction of determining the possibilities of developing this market in smaller urban and rural areas. In addition, it would be important to determine (and possibly expand) the cluster of consumers of organic products based on the opinions of consumers from smaller places. In this way, local development policies could be harmonized.

The insights gained from this study suggest several important theoretical and managerial implications aimed at increasing consumer demand for organic food. Based on the demographic and psychographic profiles identified for the three clusters of organic food consumers, key stakeholders such as organic food marketers and associations, policymakers, and socio-environmental organizations need to segregate their target policies, adjusting them for different organic consumer profiles identified in every cluster. In the long run, this should contribute to development of the local organic market and organic sector in the Republic of Serbia. Likewise, this study will enrich scientific, economic, and social literature when it comes to understanding consumers behavior at "green" or "organic" markets in developing countries.

Supplementary Materials: The following are available online at https:/ /www.mdpi.com/2071-1 050/13/1/131/s1, Table S1: F statistics for cluster analysis purposes, Table S2: Mean values for variables within a cluster, Survey: Organic Food Product Market Research.

Author Contributions: Conceptualization, V.R. and M.T.S.; methodology, M.T.S.; validation, V.R., D.M. and D.G.T.; formal analysis, V.R.; investigation, D.G.T. and M.T.S.; resources, V.R. and D.M.; data curation, V.R.; writing-original draft preparation, V.R. and M.T.S.; writing-review and editing, D.M.; supervision, D.G.T.; project administration, M.T.S. and D.G.T.; funding acquisition, V.R. All authors have read and agreed to the published version of the manuscript.

Funding: This research was funded by the Ministry for Education, Science and Technological Development of the Republic of Serbia, contract No. 451-03-68/2020-14/200117 and by Provincial Secretariat for Education, Regulations, Administration and National Minorities-National Communities contract No. 142-451-3158/2020-02.

Conflicts of Interest: The authors declare no conflict of interest.

\section{References}

1. Vapa-Tankosić, J.; Ignjatijević, S.; Kiurski, J.; Milenković, J.; Milojević, I. Analysis of Consumers' Willingness to Pay for Organic and Local Honey in Serbia. Sustainability 2020, 12, 4686. [CrossRef]

2. Tomaš-Simin, M.; Glavaš-Trbić, D.; Petrović, M. Organic production in the Republic of Serbia: Economic aspects. Ekon. Teor. Praksa 2019, 12, 88-101. [CrossRef]

3. Aarset, B.; Beckmann, S.; Bigne, E.; Beveridge, M.; Bjorndal, T.; Bunting, J.; McDonagh, P.; Mariojouls, C.; Muir, J.; Prothero, A.; et al. The European consumers' understanding and perceptions of the "organic" food regime: The case of aquaculture. Br. Food J. 2004, 106, 93-105. [CrossRef]

4. Venkat, K. Comparison of Twelve Organic and Conventional Farming Systems: A Life Cycle Greenhouse Gas Emissions Perspective. J. Sustain. Agric. 2012, 36, 620-649. [CrossRef]

5. Prodanović, R.; Ignjatijević, S.; Bošković, J. Innovative potential of beekeeping production in AP Vojvodina. J. Agron. Technol. Eng. Manag. 2019, 2, 268-277.

6. Gomiero, T. Food quality assessment in organic vs. conventional agricultural produce: Findings and issues. Appl. Soil Ecol. 2018, 123, 714-728. [CrossRef]

7. Milošević, G.; Kulić, M.; Đurić, Z.; Đurić, O. The Taxation of Agriculture in the Republic of Serbia as a Factor of Development of Organic Agriculture. Sustainability 2020, 12, 3261. [CrossRef] 
8. Puvača, N.; Lika, E.; Cocoli, S.; ShtyllaKika, T.; Bursić, V.; Vuković, G.; TomašSimin, M.; Petrović, A.; Cara, M. Use of Tea Tree Essential Oil (Melaleucaalternifolia) in Laying Hen's Nutrition on Performance and Egg Fatty Acid Profile as a Promising Sustainable Organic Agricultural Tool. Sustainability 2020, 12, 3420. [CrossRef]

9. Sarkar, A.N. Green Branding and Eco-innovations for Evolving a Sustainable Green Marketing Strategy. Asia-Pac. J. Manag. Res. Innov. 2012, 8, 39-58. [CrossRef]

10. Fernando, Y.; ChiappettaJabbour, C.J.; Wah, W.-X. Pursuing green growth in technology firms through the connections between environmental innovation and sustainable business performance: Does service capability matter? Resour. Conserv. Recycl. 2019, 141, 8-20. [CrossRef]

11. Peattie, K. Towards Sustainability: The Third Age of Green Marketing. Mark. Rev. 2001, 2, 129-146. [CrossRef]

12. Simula, H.; Lehtimäki, T. Managing greenness in technology marketing. J. Syst. Inf. Tech. 2009, 11, 331-346. [CrossRef]

13. Feil, A.A.; da Cyrne, C.C.S.; Sindelar, F.C.W.; Barden, J.E.; Dalmoro, M. Profiles of sustainable food consumption: Consumer behavior toward organic food in southern region of Brazil. J. Clean. Prod. 2020, 258, 120690. [CrossRef]

14. Falguera, V.; Aliguer, N.; Falguera, M. An integrated approach to current trends in food consumption: Moving toward functional and organic products? Food Control 2012, 26, 274-281. [CrossRef]

15. Hansmann, R.; Baur, I.; Binder, C.R. Increasing organic food consumption: An integrating model of drivers and barriers. J. Clean. Prod. 2020, 275, 123058. [CrossRef]

16. Chekima, B.; Oswald, A.I.; Wafa, S.A.W.S.K.; Chekima, K. Narrowing the gap: Factors driving organic food consumption. J. Clean. Prod. 2017, 166, 1438-1447. [CrossRef]

17. Chekima, B.; Chekima, K.; Chekima, K. Understanding factors underlying actual consumption of organic food: The moderating effect of future orientation. Food Qual. Prefer. 2019, 74, 49-58. [CrossRef]

18. Vehapi, S. A study of the consumer Motives which influence the purchase of organic food in serbia. Ekon. Teme 2015, 53, 105-121. [CrossRef]

19. Grubor, A.; Djokić, N. Organic food consumer profile in the Republic of Serbia. Br. Food J. 2016, 118, 164-182. [CrossRef]

20. Tomaš-Simin, M.; Glavaš-Trbić, D. Historical development of organic production. Ekon. Polj. 2016, 63, 1083-1099. [CrossRef]

21. Shabbir, M.S.; Bait Ali Sulaiman, M.A.; Hasan Al-Kumaim, N.; Mahmood, A.; Abbas, M. Green Marketing Approaches and Their Impact on Consumer Behavior towards the Environment-A Study from the UAE. Sustainability 2020, 12, 8977. [CrossRef]

22. Lotter, D.W. Organic Agriculture. J. Sustain. Agric. 2003, 21, 59-128. [CrossRef]

23. Margetts, B.M.; Martinez, J.A.; Saba, A.; Holm, L.; Kearney, M.; Moles, A. Definitions of "healthy" eating: A pan-EU survey of consumer attitudes to food, nutrition and health. Eur. J. Clin. Nutr. 1997, 51 (Suppl. 2), S23. [PubMed]

24. Torjusen, H.; Lieblein, G.; Wandel, M.; Francis, C.A. Food system orientation and quality perception among consumers and producers of organic food in Hedmark County, Norway. Food Qual. Prefer. 2001, 12, 207-216. [CrossRef]

25. Wier, M.; O’Doherty Jensen, K.; Andersen, L.M.; Millock, K. The character of demand in mature organic food markets: Great Britain and Denmark compared. Food Policy 2008, 33, 406-421. [CrossRef]

26. Gracia, A.; de Magistris, T. The demand for organic foods in the South of Italy: A discrete choice model. Food Policy 2008, 33, 386-396. [CrossRef]

27. Garg, N.; Wansink, B.; Inman, J.J. The Influence of Incidental Affect on Consumers' Food Intake. J. Mark. 2007, 71, 194-206. [CrossRef]

28. Nie, C.; Zepeda, L. Lifestyle segmentation of US food shoppers to examine organic and local food consumption. Appetite 2011, 57, 28-37. [CrossRef]

29. Van Huy, L.; Chi, M.; Lobo, A.; Nguyen, N.; Long, P. Effective Segmentation of Organic Food Consumers in Vietnam Using Food-Related Lifestyles. Sustainability 2019, 11, 1237. [CrossRef]

30. Migliore, G.; Thrassou, A.; Crescimanno, M.; Schifani, G.; Galati, A. Factors affecting consumer preferences for "natural wine": An exploratory study in the Italian market. BFJ 2020, 122, 2463-2479. [CrossRef]

31. Drugova, T.; Curtis, K.R.; Akhundjanov, S.B. Organic wheat products and consumer choice: A market segmentation analysis. BFJ 2020, 122, 2341-2358. [CrossRef]

32. Pacho, F. What influences consumers to purchase organic food in developing countries? BFJ 2020, 122, 3695-3709. [CrossRef]

33. Troudi, H.; Bouyoucef, D. Predicting purchasing behavior of green food in Algerian context. EMJB 2020, 15, 1-21. [CrossRef]

34. Nair, S.R.; Shams, S.M.R. Impact of store-attributes on food and grocery shopping behavior: Insights from an emerging market context. EMJB 2020. [CrossRef]

35. Wang, X.; Pacho, F.; Liu, J.; Kajungiro, R. Factors Influencing Organic Food Purchase Intention in Developing Countries and the Moderating Role of Knowledge. Sustainability 2019, 11, 209. [CrossRef]

36. Frewer, L.J.; Risvik, E.; Schifferstein, H. (Eds.) Food, People and Society; Springer: Berlin/Heidelberg, Germany, 2001; ISBN 978-3-642-07477-6.

37. Vandal, K. Trženje s sonarovnimikmetijskimipridelki. Sodobno Kmetijstvo 1997, 30, 363-369.

38. Grunert, S.C.; Juhl, H.J. Values, environmental attitudes, and buying of organic foods. J. Econ. Psychol. 1995, 16, 39-62. [CrossRef]

39. Weiner, M. Cradle to Cradle@_An analysis of the market potential in the German outdoor apparel industry. Bachelor's Thesis, Hochschule Hannover University of Applied Sciences and Arts, Hanover, Germany, 2016.

40. Yang, S.; Angulo, F.J.; Altekruse, S.F. Evaluation of Safe Food-Handling Instructions on Raw Meat and Poultry Products. J. Food Prot. 2000, 63, 1321-1325. [CrossRef] 
41. Fotopoulos, C.; Chryssochoidis, G.M.; Pantzios, C.J. Critical factors affecting the future of the Greek market of organic produce. Mediterr. J. Econ.Agric. Environ. 1999, 10, 30-35.

42. MacRae, R.J.; Lynch, D.; Martin, R.C. Improving Energy Efficiency and GHG Mitigation Potentials in Canadian Organic Farming Systems. J. Sustain. Agric. 2010, 34, 549-580. [CrossRef]

43. Magnusson, M.K.; Arvola, A.; Hursti, U.-K.K.; Åberg, L.; Sjödén, P.-O. Choice of organic foods is related to perceived consequences for human health and to environmentally friendly behaviour. Appetite 2003, 40, 109-117. [CrossRef]

44. Lockie, S.; Lyons, K.; Lawrence, G.; Grice, J. Choosing organics: A path analysis of factors underlying the selection of organic food among Australian consumers. Appetite 2004, 43, 135-146. [CrossRef] [PubMed]

45. Tsakiridou, E.; Boutsouki, C.; Zotos, Y.; Mattas, K. Attitudes and behaviour towards organic products: An exploratory study. Int. J. Retail. Distrib. Manag. 2008, 36, 158-175. [CrossRef]

46. Ness, M.R.; Ness, M.; Brennan, M.; Oughton, E.; Ritson, C.; Ruto, E. Modelling consumer behavioural intentions towards food with implications for marketing quality low-input and organic food. Food Qual. Prefer. 2010, 21, 100-111. [CrossRef]

47. Stolz, H.; Stolze, M.; Hamm, U.; Janssen, M.; Ruto, E. Consumer attitudes towards organic versus conventional food with specific quality attributes. NJAS Wagening. J. Life Sci. 2011, 58, 67-72. [CrossRef]

48. Ignjatijević, S.; Prodanović, R.; Bošković, J.; Puvača, N.; Tomaš-Simin, M.; Peulić, T.; Đuragić, O. Comparative analysis of honey consumption in Romania, Italy and Serbia. Food Feed Res. 2019, 46, 125-136. [CrossRef]

49. Brkanlić, S.; Sánchez-García, J.; Esteve, E.B.; Brkić, I.; Ćirić, M.; Tatarski, J.; Gardašević, J.; Petrović, M. Marketing Mix Instruments as Factors of Improvement of Students' Satisfaction in Higher Education Institutions in Republic of Serbia and Spain. Sustainability 2020, 12, 7802. [CrossRef]

50. Tatarski, J.; Brkanlić, S.; Sanchez Garcia, J.; Esteve, E.B.; Brkić, I.; Petrović, M.; Okanović, A. Measuring Entrepreneurial Orientation of University Employees in Developing Countries Using the ENTRE-U Scale. Sustainability 2020, 12, 8911. [CrossRef]

51. National Research Council (US); Institute of Medicine (US); Woolf, S.H.; Aron, L. Public Health and Medical Care Systems; National Academies Press: Washington, DC, USA, 2013.

52. Scaglioni, S.; De Cosmi, V.; Ciappolino, V.; Parazzini, F.; Brambilla, P.; Agostoni, C. Factors Influencing Children's Eating Behaviours. Nutrients 2018, 10, 706. [CrossRef]

53. Canio Francesca, D.; Elisa, M. EU quality label vs Organic food products: A multigroup structural equation modeling to assess consumers' intention to buy in light of sustainable motives. Food Res. Int. 2020, 109846, In Press, Corrected Proof. [CrossRef]

54. Ditlevsen, K.; Denver, S.; Christensen, T.; Lassen, J. A taste for locally produced food-Values, opinions and sociodemographic differences among 'organic' and 'conventional' consumers. Appetite 2020, 147, 104544. [CrossRef] [PubMed] 